\title{
Sustainable Approaches to
} the Construction of Roads and Other Infrastructure in the Hindu Kush-Himalayas

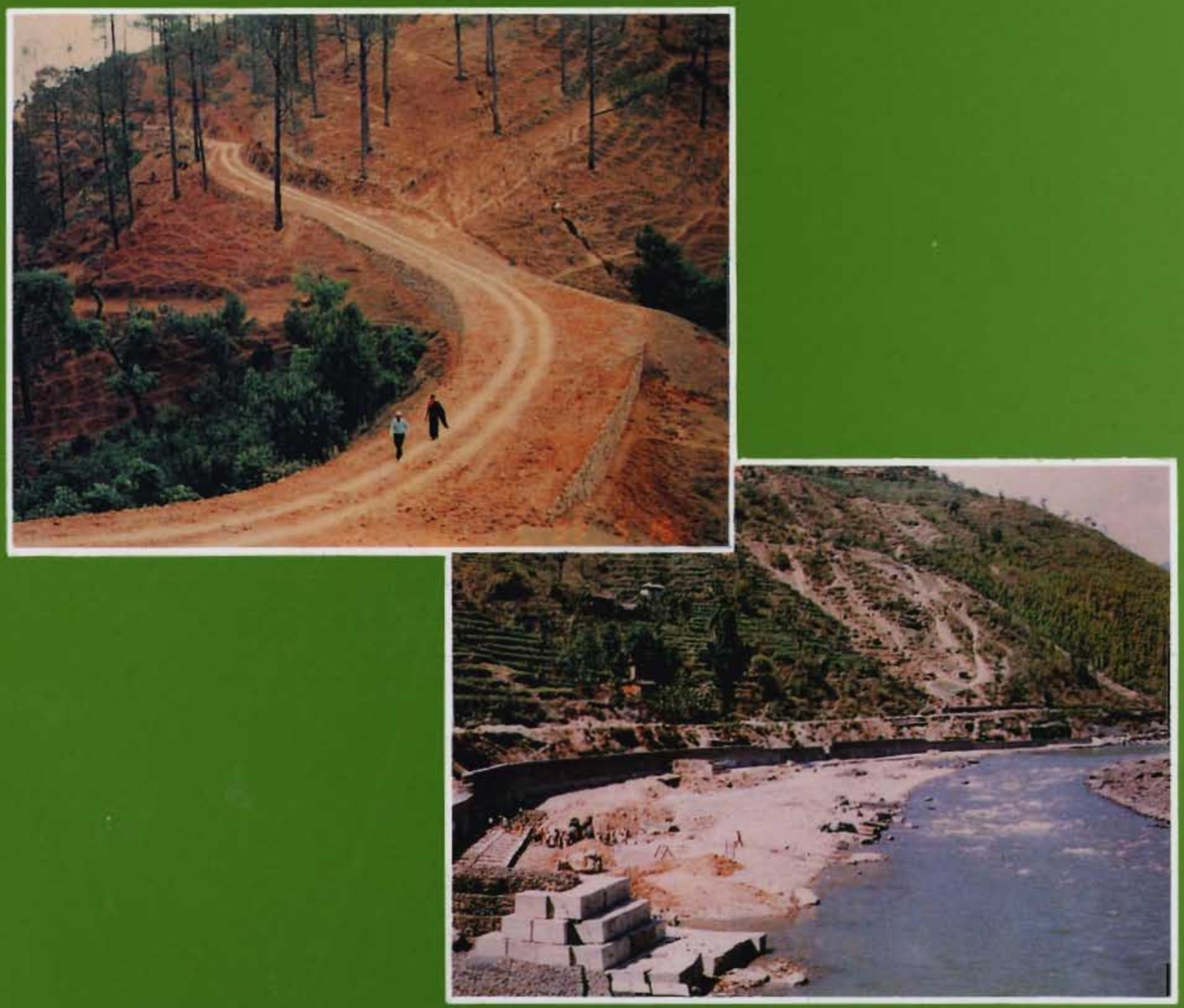

Birendra B. Deoja

ICIMOD OCCASIONAL PAPER NO. 24

Kathmandu, NEPAL 


\section{ICIMOD Occasional Papers}

No. 1 EROSION AND SEDIMENTATION PROCESSES IN THE NEPALESE HIMALAYA Brian Carson (1985)

No. 2 INTEGRATED RURAL DEVELOPMENT PROJECTS IN NEPAL: A REVIEW Bharat B. Pradhan (1985)

No. 3 SUSTAINING UPLAND RESOURCES: PEOPLE'S PARTICIPATION IN WATERSHED MANAGEMENT

Anis Dani and J.G. Campbell (1986)

No. 4 DECENTRALIZED ENERGY PLANNING AND MANAGEMENT FOR THE HINDU KUSHHIMALAYA

Deepak Bajracharya (1986)

No. 5 GLACIAL LAKE OUTBURST FLOODS AND RISK ENGINEERING IN THE HIMALAYA Jack D. Ives (1986)

No. 6 OPERATIONAL EXPERIENCES IN FOREST MANAGEMENT DEVELOPMENT IN THE HILLS OF NEPAL

G.B. Applegate and D.A. Gilmour (1987)

No. 7 FORESTRY-FARMING LINKAGES IN THE MOUNTAINS

T.B.S. Mahat (1987)

No. 8 ROAD CONSTRUCTION IN THE NEPAL HIMALAYA: THE EXPERIENCE FROM THE LAMOSANGU-JIRI PROJECT

Urs Schaffiner (1987)

No. 9 MOUNTAIN ENVIRONMENTAL MANAGEMENT IN THE ARUN RIVER BASIN OF NEPAL John R. Dunsmore (1988)

No. 10 HILL AGRICULTURE AND THE WIDER MARKETING ECONOMY:

TRANSFORMATION PROCESSES AND EXPERIENCE OF THE BAGMATI ZONE IN NEPAL Mahesh Banskota (1989)

No. 11 HIGHLAND-LOWLAND INTERACTIONS IN THE GANGES BRAHMAPUTRA RIVER BASIN: A REVIEW OF PUBLISHED LITERATURE

L.A. Bruijnzeel and C.N. Bremmer (1989)

No. 12 MICRO-LEVEL ENVIRONMENTAL MANAGEMENT OBSERVATIONS ON PUBLIC AND PRIVATE RESPONSES IN KAKANI PANCHAYAT, NEPAL

Saroj K. Basnyet (1989)

No. 13 MOUNTAIN ENVIRONMENTAL MANAGEMENT: NYEMO COUNTY (TIBET), CHINA Zhang Rongsu (1989)

No. 14 NATURAL RESOURCE MANAGEMENT IN THE MOUNTAIN ENVIRONMENT: EXPERIENCES FROM DOON VALLEY, INDLA

J. Bandyopadhyay (1989)

No. 15 LANDSLIDE MANAGEMENT IN THE MOUNTAIN AREAS OF CHINA

Li Tianchi (1990)

No. 16 MINI- AND MICRO-HYDROPOWER IN NEPAL Jean-Marion Aitken, G. Cromwell, and G. Wishart (1991)

No. 17 AGROFORESTRY IN MOUNTAIN AREAS OF THE HINDU KUSH-HIMALAYAN REGION Jeannette Denholm (1991)

No. 18 HYDROLOGICAL ASPECTS OF THE HIMALAYAN REGION Donald Alford (1992)

No. 19 SUSTAINABILITY OF THE ENVIRONMENTAL RESOURCE BASE AND DEVELOPMENT PRIORITIES OF A MOUNTAIN COMMUNITY: BHARDEO, NEPAL

Kk Panday (1992)

No. 20 SEABUCKTHORN: A MULTIPURPOSE PLANT SPECIES FOR FRAGILE MOUNTAINS Lu Rongsen (1992)

No. 21 THE LAND, THE FARMER, AND THE FUTURE:

A SOIL FERTILITY MANAGEMENT STRATEGY FOR NEPAL

Brian Carson (1992)

No. 22 INYNAMICS OF HIGHLAND AGRICULTURE IN LHASA DISTRICT, TIBET Liu Yanhua (1992)

No. 23 SLOPING AGRICULTURAL LAND TECHNOLOGY (SALT): A REGENERATIVE OPTION FOR SUSTAINABLE MOUNTAIN FARMING

Tej Partap and Harold R. Watson (1994) 
Sustainable Approaches to the Construction of Roads and Other Infrastructure in the Hindu Kush-Himalayas

Birendra B. Deoja

ICIMOD OCCASIONAL PAPER No. 24

Published by

International Centre for Integrated Mountain Development

Kathmandu, Nepal 
Copyright (C) 1994

International Centre for Integrated Mountain Development

All rights reserved

Cover photograph: Top: Environmentally-friendly, low-cost road built with local participation, Palpa (D.C. Joshi - East Consult)

Bottom : Road constructed after rigorous engineering and geological considerations, the Arniko Highway (B. Sherchan - ITECO)

\section{Published by}

International Centre for Integrated Mountain Development

G.P.O. Box 3226,

Kathmandu, Nepal

\section{ISBN 92-9115-208-0}

Typesetting at ICIMOD Publications' Unit

The views and interpretations in this paper are those of the author(s). They are not attributable to the International Centre for Integrated Mountain Development (ICIMOD) and do not imply the expression of any opinion concerning the legal status of any country, territory, city or area of its authorities, or concerning the delimitation of its frontiers or boundaries. 


\section{Foreword}

Infrastructural development in the Hindu Kush-Himalayas is an undertaking associated with what sometimes seems like an insurmountable array of hazards. Every piece of infrastructure established is at a risk from washouts and failures resulting from erosion, gullying, and landslides. Such problems are exacerbated by deforestation, natural events, and other human interventions that lead to mass movements of soils, rocks, etc. This is a huge challenge for planners in the HKH Region where the instability of the terrain is most sensitive to faulty planning.

In accordance with ICIMOD's primary objectives as: (i) a multidisciplinary centre on integrated mountain development, (ii) a focal point for mobilising, concluding, and coordinating applied and problem-solving research, (iii) a focal point for training, and as (iv) a consultative centre to provide expert services on integrated mountain development in the HKH Region - one of the tasks of ICIMOD is to undertake networking and information exchange activities on appropriate Mountain Technology. This current volume examines the appropriateness of different approaches to constructing roads and infrastructure in mountainous regions. In doing so, it has drawn upon experiences from across the HKH Region but concentrates primarily on the case of Nepal.

For a predominantly mountainous country like Nepal, where the establishment of infrastructure is characterised by high initial costs, frequent damages due to harsh terrain and heavy monsoon rains, long construction time, and low economic returns; and where the establishment of infrastructure is seen as a sine qua non for development; there is a need for serious rethinking about land-use plans, development strategies, and infrastructural practices.

This paper by Birendra Deoja is aimed at creating a wareness about the various considerations necessary for the sustainable development of infrastructure in mountainous regions. In writing this Occasional Paper for ICIMOD, Mr. Deoja has drawn on a wealth of experience gathered during his term of office at the Department of Roads, HMG/Nepal, and during his tenure at ICIMOD where he was Team Leader for the compilation of the Mountain Risk Engineering Handbook. This present document will make a valuable addition to the rather scant body of knowledge on the construction of roads in the Hindu Kush-Himalayas.

Egbert Pelinck

Director General 


\section{Acknowledgements}

I am grateful to Dr. E.F. Tacke, the previous Director General of ICIMOD, and Dr. M. Banskota, Director of Programmes, ICIMOD, for providing me with the opportunity to write this paper for ICIMOD. I am thankful to my engineer colleagues in the Department of Roads, Durga Prasad K.C., Bindu S. Rana, and Kamal Pande, for providing me with valuable photos of the road washouts that occurred during July 1993. Similarly, thanks are due to Bijaya Sherchan of ITECO Nepal for photos from the Thankot-Naubise Road and the Arniko Highway.

I express my thanks to P.C. Joshi of East Consult for providing photos of low-cost road construction on the Palpa Road and for his many valuable contributions on the social approach to low-cost, village level and participatory road programmes as well as environmental awareness through action-research.

Special thanks are due to Jyoti Ghimire, engineer, for assisting me in writing this paper. Ghanashyam Acharya deserves special thanks for organising and compiling the paper.

Birendra B. Deoja 


\section{Contents}

1. Introduction

2. Traditional Approaches

3. Specific Concerns $\quad 4$

Engineering Geology 4

Environmental Concern $\quad 14$

$\begin{array}{lr}\text { Socioeconomics } & 21\end{array}$

Engineering 25

Planning, Decision-making, and Communication Gap $\quad 36$

$\begin{array}{ll}\text { 4. Road Washouts in Nepal } & 40\end{array}$

$1979-40$

$1981 \quad 40$

$\begin{array}{ll}1983 / 84 & 40\end{array}$

1987 a 190

1991 - 40

$1993 \quad 41$

Prithvi Rajmarg, Naubise-Mugling Section $\quad 41$

Tribhuvan Rajpath, Naubise-Hetauda Section $\quad 41$

\begin{tabular}{l|l} 
Phidim-Taplejung Highway & 41
\end{tabular}

5. The Context of Mountain Road Planning 42

6. Low Cost Mountain Roads 48

7. Mountain Risk Engineering (MRE) $\quad 49$

Background $\quad 49$

MRE Definitions and Concepts $\quad 49$

Hazard and Risk Assessment

MRE Application in Nepal

8. Conclusions and Recommendations 53

$\begin{array}{ll}\text { Annexes } & 54\end{array}$

1: Summary of Road Status and Costs of Construction,

Periodic Maintenance, and Upgrading in Nepal - by Classification $\quad 54$

2: $\quad$ Summary of Road Status and Costs of Construction,

Periodic Maintenance, and Upgrading in Nepal - by Region $\quad 55$

Plates 


\section{TABLES}

1: $\quad$ The Himalayan System

2: $\quad$ Classification of the Problems of Mass Wasting

3: $\quad$ Power of Flowing Water

4: $\quad$ Exceptionally Heavy Rainfall and Devastating Landslides

5: $\quad$ Landslides in China That Have Killed At Least 100 People

6: $\quad$ List of Major Natural Hazards in the Nepal Himalayas

7: Devastating Earthquakes in the Himalayan Region

8: $\quad$ Historic Earthquakes of Greater Magnitude and Effects in Southwest China

9: $\quad$ Historical Earthquake Events in Nepal

10: The Maximum Points of the 10 Major Rainfalls in China

11: Characteristic Values of Rainfall during Landslide Occurrence in Sichuan Basin

(July 1982)

12:

13:

14:

15:

16:

17:

18:

19:

20:

21:

Typical Landslides Induced by Rainfall in Eastern Sichuan Basin (July 1982)

Precipitation Levels Triggering Landslides in Gansu Province

Rainfall Thresholds for Rainfall Triggered Landslides in Different Rocks in China

Karnali River Sediment Load (million tonnes/year)

Denudation Rate in the Sunkoshi Basin, Nepal

Sediment Load in Nepalese Rivers

Accepted Rates of Tolerable Soil Loss

Decision-making on Choice of Alignment

Recommended Geometric Standards for Mountain Roads

Indicative Quantities of Major Items of Hill Road for Height of Cut Limited to

Less than $12 \mathrm{~m}$ and Low-risk Designs of Cross-sections

Outlines for Conservation-oriented Hill Roads

Road Density of Selected Countries

Road Density in Nepal

Road Networks in Nepal - Eighth Plan

Road Networks in Nepal for a 26 km/100 sq.km. Road Density

\section{FIGURES}

1: $\quad$ The Eroded and the Cultivated Landscape

The Assessment of a Man-environment System

Schematic Illustration of the Pattern of Interaction between Man and Nature

in the Usambara Mountains

5: $\quad$ Spiral of Economic and Infrastructural Growth and

Landscape Change under the Influence of Tourism

6: In rocky areas, where excavation is difficult and expensive, the centre line shifts towards the valley and reduces the height of cut and volume of excavation to a great extent

7: $\quad$ A breast wall founded on the sound rock supports the cut slope and greatly reduces the amount of excavation. Cut height is much smaller and hazards and risks are reduced significantly

8: $\quad$ Minimising height of cut on steep slopes is possible by providing breast walls and shifting the centre line horizontally as shown in the figure to the right.

9: $\quad$ On very steep slopes, breast wall construction is not feasible. By shifting the centre line horizontally and providing a back-battered retaining wall towards the downhill side of the road, the volume of excavation is reduced

A Composite wall (consisting of dry masonry and cement masonry) is suitable and economical whenever the foundation is sound

11: A Cement masonry wall can be constructed economically in rocky areas because benching of the foundation is possible and the backfill wedge may also be smaller A Back-battered, Front-battered Retaining Wall

13: A high water table in the bank slope, due to change in flood level, weakens the bank 